\title{
FRANZ FANON Y LOS ESTUDIOS LITERARIOS POSTCOLONIALES
}

MARÍA JosÉ VEGA

Universidad Autónoma de Barcelona

Introducción: de Peau NoIre (1952) a Les damnés de la terre (1961)

Dos obras de Franz Fanon ha tenido una influencia determinante en los estudios comparados y en la crítica literaria postcolonial desde los años ochenta: el ensayo Piel negra, máscaras blancas (Peau noire, masques blanches), un "Sociodiagnóstico de la colonización" publicado en París en 1952; y una de sus obras póstumas y más abiertamente políticas, en la que propone un modo de entender y periodizar las nuevas literaturas nacionales en los países surgidos de la descolonización, Los malditos de la tierra (Les damnés de la terre), que Jean-Paul Sartre hizo imprimir en París en 1961, poco después de la muerte de su autor. Franz Fanon, negro, había nacido en 1925 en la colonia francesa de la Martinica; fue voluntario en la segunda guerra mundial y, posteriormente, estudió medicina en Francia. Ejerció profesionalmente la psiquiatría y vivió en las Antillas, en Francia y en Africa durante la guerra de independiencia de Argelia, en la que participó activamente ${ }^{1}$.

1 Fanon dejo Martinica en 1943, a los dieciocho años, para luchar en la segunda guerra mundial. Tras la guerra permanecí en Lyon con una beca del gobiemo francés, y allí comenzó a escribir sus primeras obras. A partir de 1953 dirigió el departamento de psiquiatría del Hospital Blida- 
Se ha juzgado a Fanon como un teórico de la resistencia anticolonial y como un apóstol de la violencia necesaria: es también un analista de la alienación del negro y un extremista y activista político. Su fama generalizada se debió quizá a Les damnés de la terre, el más virulento de sus libros, que estaba precedido por un prólogo no menos explosivo de Jean-Paul Sartre. No se ha investigado, en cambio, suficientemente, la relación de Fanon con los estudios literarios, ni el hecho de que en su obra clínica y política comparezcan claramente algunos de los conceptos fundantes de la teoría literaria y del comparatismo postcolonial, ni tampoco las vías por las que un psiquiatra negro de la Martinica puede convertirse en una importante llave conceptual de una de las ramas más radicales y recientes de los estudios literarios metropolitanos. Es la tesis principal de estas páginas que en la obra de Fanon se encuentra una de las vetas ideológicas que permite explicar mejor y más cabalmente el mapa intelectual de la teoría postcolonial contemporánea, del nuevo comparatismo, y de la ideología que los inspira. No parece haberse advertido que a ella se remontan muchos de los términos y conceptos considerados más innovadores y eficaces para tratar con la literatura de las antiguas colonias, como la idea del mimetismo, de resistencia cultural, de ambivalencia e hibridación.

A pesar de que escribió en la década de los cincuenta, la presencia de Fanon en la teoría postcolonial anglosajona se produce no tanto a partir de la primera traducción al inglés de Les damnés de la terre (The Wretched of the Earth, 1969), cuanto de la traducción de Peau noire, masques blanches (Black Skins, White Masks) de C. L. Markmann, que apareció en Londres en 1986 acompañada de un estudio introductorio de Homi K. Bhabha, Foreword: Remembering Fanon, que favoreció extraordinariamente la difusión de la obra fanoniana en los medios de la teoría y la crítica angloamericanas ${ }^{2}$. Es posible que la singular influencia de Bhabha, cuya obra está literalmente repleta de referencias (aunque a menudo no reconocidas) a Les Damnés y Peau noire, y su

Joinville, en Argelia. Cuando estalla la guerra de independencia, Fanon se aleja progresivamente de la administración francesa, hasta el punto de que renuncia a su cargo en 1956 y se adhiere a la causa de la independencia argelina. Fue editor del periódico anticolonial El Moujahid (El luchador de la libertad); participó activamente en el FLN y en 1960 fue embajador del gobierno provisional de Argelia en Ghana, donde escribio, en apenas diez meses y aquejado de leucemia, Les damnés de la terre. A partir de 1956 colaboró en Les temps modernes, de Sartre, y en Présence Africaine. Es también autor de $L$ 'an $V$ de la révolution algérienne [1959] y el póstumo Pour une révolution africaine [1964], que no consideraré en estas páginas porque no abordan problemas literarios ni materias que, posteriormente, hayan sido relevantes para el curso de la teoría y la crítica de las literaturas postcoloniales.

2 Внавна [1993: 112-123; 1994: 40-65]. Participó también en el reciente documental Frantz Fanon: Black Skins, White Masks (1996) de Isaac Julien. 
invocación expresa de Fanon en algunos de sus trabajos, hayan contribuido a la resurrección, para los estudios literarios, de estas dos obras. Poco después, en Culture and Imperialism (1993) de Edward Said, podía encontrarse una conspicua atención a Fanon como teórico de la resistencia estética y literaria. En esta corriente de recuperacion, se ha producido un movimiento pendular por el que los estudios sobre la francofonía han vuelto con renovado interés sobre la obra fanoniana ${ }^{3}$. Si el primer gran éxito editorial de Fanon, y su modo de llegar a un público de jóvenes airados negros, de activistas de izquierda y de estudiantes soixante-huitards fue el texto de Les damnés, siempre acompañado del violento prólogo sartriano, su segundo éxito de influencia, esta vez de naturaleza académica, parece haber llegado de su obra más clínica y menos abiertamente política, Peau noire ${ }^{4}$.

Se propone aquí una lectura parcial de Franz Fanon, esto es, una lectura de aquellas páginas de su obra que se revelarán importantes en la crítica y el comparatismo de los años ochenta y noventa. No es pues de interés primario el Fanon revolucionario y radical, sino el primer Fanon clínico, que teoriza la construcción cultural de la imagen del negro y el mimetismo del colonizado y que acude a las ficciones literarias para estudiar cómo se construye la identidad individual; y también el último Fanon, que analiza el nacionalismo cultural y la literatura nacional como forma de resistencia. Interesa pues el Fanon que critica e invalida la pretendida universalidad del psicoanálisis (de Freud, Lacan, Mannoni) o que mantiene relaciones estrechas, tanto para la adhesión como la objeción, con el pensamiento de Sartre y el movimiento de la négritude. Se propone por ello una lectura atípica, y, en cierto modo, retrospectiva, ya que pretende

3 Véase sólo Moura [1997]. La traducción castellana de Les damnés, que apareció en Méjico en 1963 como Los condenados de la tierra, ha sido objeto de continuas reimpresiones, si bien su influencia se ha ejercido más netamente en el ámbito político radical latinoamericano que en los estudios literarios. Baste recordar el lugar conspicuo que le reserva Alvaro Vargas Llosa entre «los diez libros que conmovieron al idiota latinoamericano».

- El aprecio de Fanon ha estado relacionado con lo que hay en sus obras de teoría política o de analista de la colonización (cfr. GEISMAR [1971] y GORDON [1970]). Young [1995: 161] le califica de «padre fundador» de la «teoría anticolonial»; CHILDS [1997:27] le concede un lugar de privilegio entre los estudiosos de la «resistencia textual» y la «mitología» de la colonizacion; AsHCROFT [et al., 1989: 29] lo celebra como analista de la dialéctica del imperio y la colonia y de las consecuencias psicológicas y sociológicas de la colonización; como un térico de la identidad negra, de la escritura negra, de la negritud en la diáspora [1989: 124-125]. Ha sido considerado como un «modelo clásico» de unión de analisis y conciencia política [PARRY, 1987: 30; y sobre todo GATES, 1991: 457-470]. De la continua actualización de su aproximación psicoanalítica es buena muestra VERGĖs [1997: 578-595]. Por su parte, POSNOCK [1997: 323-349] encuentra en el fanonismo una renovada inspiración ética para el intelectual negro. La influencia de Fanon es evidente en estudios como los de GABRIEL [1989: 30-52] y FrANCo [1988 / 1993]. 
subrayar los aspectos relacionados con los estudios literarios o con el uso identitario de la literatura por parte de los nacionalismos emergentes. Revisaré en primer lugar el sociodiagnóstico de la alienación del negro (Peau noire) y la relación de la literatura con esa alienación, y, en segundo lugar, el concepto de resistencia textual y de nueva literatura nacional (Les damnés).

Antes de comenzar, no obstante, es necesario llevar a cabo un examen sumario del contexto que permite comprender cabalmente el movimiento opositivo de Fanon y de los textos que hacen posible su obra (contra la ideología celebratoria de la négritude, contra el negro emocional senghoriano, contra la exaltación indiscriminada del Orphée noir de Sartre) a pesar de la novedad de sus planteamientos. La breve revisión de la negritud pre-fanoniana y de su programa literario y político requiere comenzar unos años antes, con la publicación de las obras de Aimé Césaire y de las antologías poéticas de Léopold Senghor y de Léon Damas, y con la formación de la poética de la negritud.

ORFEO NEGRO: POÉTICA Y POLITICA DE LA NEGRITUD

"Voici des hommes noirs debout qui nous regardent et je vous souhaite de ressentir comme moi le saisissement d'être vus»

(Jean Paul Sartre, Orphée noir).

El movimiento de la négritude nació en París. Es posible que su primera manifestación fuera un texto programático publicado en 1932, Légitime Défense, que recoge las aspiraciones literarias y políticas que se materializarían más tarde en torno a la editorial Présence Africaine, fundada por Léon Damas (de Guyana), Aimé Césaire (de Martinica) y Léopold Senghor (de Senegal) ${ }^{5}$. Este grupo reunía a negros antillanos y americanos con negros africanos, y los reunía por su relación con un mismo centro metropolitano y su pertenencia al ámbito de la francofonía. El movimiento de la negritud, no obstante, no surgiría plenamente hasta finales de la década de los cuarenta, en la inmediata posguerra europea, y está definitivamente vinculado al proyecto intelectual, cultural y político de Léopold S. Senghor.

5 En 1932, apareció el primer y único número de la revista Légitime Défense, que contenía un encendido rechazo de la «personalidad prestada» y de los modelos poéticos europeos - o, al menos, de los más escolares, como Hugo- y se adhería al surrealismo y a la causa del proletariado (a Marx, a Freud, a Rimbaud, a Breton, por cierto, también europeos). En 1934, Senghor, Damas y Césaire fundaron la revista $L^{\prime}$ Etudiant Noir y, en 1947, la editorial Présence Africaine. 
La négritude es una acuñación del poeta Aimé Césaire, que había vuelto de París a su país natal, la Martinica, en 1939, para ejercer como profesor en un liceo de Fort-au-France. En ese año publicó un extenso poema titulado Cahier d' un retour au pays natal, que versa sobre la opresión colonial en Martinica y el redescubrimiento de la africanidad del negro antillano. El país natal del poema era un lugar híbrido, sin orígenes, con una historia obliterada, una lengua ajena, un presente lamentable: fue en el Cahier donde apareció por primera vez el término négritude, y quizá por ello el texto ha sido considerado como una suerte de manifiesto de este movimiento, $o$, al menos, como una provocación y una denuncia de la sociedad colonial ${ }^{6}$. Pero la irrupción de la literatura negra de lengua francesa en el panorama metropolitano se produce realmente con la fundación de la editorial Présence Africaine (1947), la aparición de los Poètes d'expression française del guyanés Léon Damas (1947), y, sobre todo, de la Anthologie de la nouvelle poésie nègre et malgache de Léopold Sédar Senghor (1948) ${ }^{7}$. La Anthologie estaba prologada con el (luego) célebre ensayo Orphée noir de Jean Paul Sartre, que constituye una suerte de manifiesto de la poética y la política de la negritud ${ }^{8}$. Con la antología de Senghor habría comenzado a producirse lo que se ha dado en llamar la «inversión simbólica», esto es, la resistencia cultural que no se reduce a la defensa del negro y a la mostración de los abusos coloniales, sino que pretende el examen ideo-

${ }^{6}$ El Cahier, que salió en 1939 en una revista de París, Volontés, fue publicado en ingless en Nueva York, en 1947, con prólogo de André Breton, y después en París por Bordas. A partir de 1956 lo han reimpreso con frecuencia los talleres de Présence Africaine. En 1946, Gallimard editó Les armes miraculeuses, la colección de poemas surrealistas de Césaire que habían ido apareciendo en la revista Tropiques. Los historiadores de la literatura entienden que la obra de Césaire supuso una importante inflexión en la literatura antillana que, antes, habria sido una literatura «europea» o «de europeos»: los primeros escritores antillanos fueron colonos blancos o del tipo que Fanon califica de asimilacionista o de calcomanía. Las obras más abiertamente políticas y combativas de CÉSAIRE son Discours sur le colonialisme (1955) y la Lettre à Maurice Thorez (1956). Tuvo también un notable éxito la trilogía dramática La tragédie du roi Christophe (1963), Una saison au Congo (1966) y Une tempête (1968).

7 Además de editor de la Anthologie, SENGHOR es autor de Chants d'ombre (1945), quizá su obra más conocida. Siguieron Hosties Noires (1948), Ethiopiques (1956) y los poemarios Nocturnes (1961), Lettres d' Hivernages (1972), Élégies majeures (1979). Sus textos literarios, artículos y discursos se han agrupado, entre 1964 y 1983, en cuatro volúmenes, bajo el título común de Liberté. Sobre la biografía política de Senghor vid. SEGAL [1962 / 1964: 317-326].

${ }^{8}$ Los movimientos anteriores de literatura negra, como la Harlem Renaissance o el movimiento indigenista haitiano, no habían formulado explícitamente sus principios críticos y teóricos. A la zaga del Orphée escribiría Mário de Andrade su Prefácio a la Poesia negra de expressâo portuguesa [1953]; aparecería, en 1957, la revista nigeriana en lengua inglesa Black Orpheus, dedicada a la literatura y la crítica africanas [cfr. CHEVRIER, 1984] y Jahn publicaría la colección Schwarzer Orpheus [1964]. 
logico de la mission civilisatrice francesa ${ }^{9}$. Quizá por ello la Anthologie tuvo un extraordinario impacto literario y político. Baste recordar con qué emoción dice Amílcar Cabral haber recorrido el libro en 1949 para encontrar en él «coisas que nem sonhava; poesias maravilhosas escritas por negros de todas as partes do mundo francês, poemas falando da África, dos escravos, dos homens, da vida e das aspiraçôes dos homens. Versos como isto. Nègre colporteur de révolte..» Y, sobre todo, Cabral entendió la Anthologie como el nuncio de una inminente revolución ( $«$ Muito me traz este livro, e entre muito, a certeza de que o Negro, o tâo explotado Negro está acordando em todo o Mundo...») y fundó en ella su desprecio por los «asimilados» del arte poética, por la poesía envenenada, por los «pequenos Camôes de pele preta, os ínfimos Anteros idem» ${ }^{10}$.

En el Orphée, Sartre identificaba las características principales de lo que dio en llamar la «epifanía poética» de la negritud: saludaba «la pasión del sufrimiento, la búsqueda de la identidad perdida, la vuelta al país natal, el descenso a los infiernos resplandecientes del alma negra, el auto de fe del lenguaje» y aplaudía el carácter escandaloso de este movimiento poético, «escandaloso, entiéndase, para los europeos por derecho divino, habituados, desde hace siglos, a ver sin ser vistos». Sartre introdujo a los lectores europeos la poesía africana y negra desde una optica política y con un tono exaltado: la nueva negritud aparecía como una liberación, una recuperación de la voz (porque elimina la mordaza «que tapaba la boca negra») y una recuperación de la mirada («hoy, los hombres negros nos miran, y es nuestra propia mirada la que regresa a nuestros ojos», Orphée 5). La Anthologie de Senghor alcanzaba así dimensiones evangélicas, era el nuncio de la buena nueva de la recuperación de la negritud, si bien su destino último, a saber, la plena realización del hombre en una sociedad sin razas, exigía que también la negritud desapareciera, o se destruyera, al alcanzar su objetivo y culminación.

Suele concederse que la négritude es la primera gran ruptura con el Africa colonial, y que la Anthologie es el acta de nacimiento de la littérature de la négritude ${ }^{11}$. Senghor llama a la negritud un nom de passe, una contraseña, un

9 Sobre la idea de la inversión simbolica de Senghor, vid. Moura [1997: 69]. Sobre la poesía de la negritud y, en general, sobre la poesía negra en francés vid. JouBERT et al. [1986: 21-90]; ChEVRIER [1984]. Los estudios clásicos fueron los de KEsTeloot [1965] y CORNEvin [1976]. Sobre la négritude en particular, vid. HAUSSER [1982 passim].

10 Carta de Amilcar Cabral del 12 de abril de 1949: vid. Mário de Andrade «A cultura na problemática da libertaçâo nacional», reproducida en Poesia negra de expressáo portuguesa, 30 y 25.

11 Vid. sólo JOUBERT [1986: 23] para su extensión en el mundo francófono. En el ámbito lus6fono la poética de la negritud fue relevantísima. En 1947, cuando se edita en París Présence Africaine, los estudiantes negros africanos de la Casa dos Estudantes do Império, en Coimbra, mimeografiaron el primer número de la revista Meridiano. En 1953, dos jóvenes, Francisco Tenreiro y 
signo de reconocimiento, una vindicación. El programa político implícito en la literatura de la negritud es el de levantarse contra la negación europea de los valores africanos, que se había desarrollado para justificar la esclavitud, el sometimiento y la colonización de Africa. La negritud, pues, se define como un proyecto intelectual de rehabilitación, y es, por ello, un proceso de inversión, una construcción mítica de una imagen del negro que pueda constituirse en el orgulloso reverso de la denegación europea. El género dominante de la literatura de la negritud es la poesía lírica, que se autodefine como poesía dolorosa y como la exploración de un pays de souffrance ${ }^{12}$; el tema dominante, la celebración de ser negro y la lamentación simultánea por serlo, ya que el negro se percibe a sí mismo como un nuevo Cristo o un nuevo Mesías. Sartre describe al Negro de la Negritud, en el Orphée, como un hombre que ha asumido para sí todo el dolor humano ( LLe noir conscient de soi se présente à ses propres yeux comme l'homme qui a pris sur soi toute la doleur humaine et qui souffre pour tous, même pour le blanc») ${ }^{13}$. Es también Sartre el que lo cifra en la imagen de Orfeo, no sólo por el canto y la poesía, sino porque ha descendido a los infiernos del alma negra, esto es, de la identidad perdida o robada, antes de poder retornar y redescubrir un pasado glorioso en la tradición africana y una suerte de paraíso en forma de negritud original y de serenidad primigenia.

Surgen así los mitos de la negritud contra los que tan vehementemente reaccionará Fanon. La poesía de la negritud es la poesía de la nostalgia de una imagen de Africa, milenaria, tradicional y grandiosa: exalta $\longrightarrow$ inventa- un Africa de guerreros valerosos y sabanas ancestrales (como decía un poema de David Diop), que encierra el secreto de una suerte de armonía cósmica, de una comunicación continua entre dioses y hombres, entre vivos y muertos, entre plantas y animales. A fuerza de exaltar la civilización africana, y el mesianismo del nuevo Negro de la negritud, Léopold Senghor llega a afirmar que la cultura de los negros debe aportar un «suplemento de alma» (supplément d'âme) a las culturas metropolitanas e industriales (del «mundo difunto») ${ }^{14}$. El negro literario senghoriano, el Negro-Negro, como le lla-

Mário de Andrade, publicaron en Lisboa un exiguo cuadernillo de dieciocho páginas titulado Poesia negra de expressâo portuguesa que se inspiraba, directamente, en la Anthologie.

12 La expresión de pays de souffrance como patria del negro es de David Diop, en Présence Africaine (cfr. JOUBERT, 1986: 78). En Pigments, de Leon Damas, también aparece el sentimiento doloroso racial y las humillaciones sumadas por ser negro.

${ }^{13} \mathrm{Cfr}$. Sartre, Orphée, 7. El poema-manifiesto de esta idea cristológica del negro es La ronde des jours de Bemard Dadié: «Je vous remercie mon Dieu, de m'avoir cré Noir, / d'avoir fait de moi / la somme de toutes les douleurs, / mis sur ma tête / le Monde». Vid. JoubERT [1986: 23b] y los comentarios sobre este poema en Hausser [1982: 53].

14 Vid SHENGOR, Chant d'ombre, 12. 
mará Fanon, se convierte en una suerte de héroe civilizador y en redentor poético del mundo ${ }^{15}$.

La négritude de Senghor es, ciertamente, un movimiento de resistencia y de liberación, no sólo porque designe un movimiento de escritura literaria del Africa negra, sino porque es también un movimiento en contra de la consideración del negro como ser inferior o dependiente: es, pues, una estrategia de revalorización, aprecio, ponderación de todas las características que se consideran propias de la cultura negra y que pueden oponerse a los estereotipos europeos. Los ensayos de Senghor no sólo quieren explicar la cultura africana, sino, sobre todo, subrayar lo que tiene de bello, de admirable y grandioso. En este sentido, la política de la négritude pretende, sub specie fabulae, la recuperación del orgullo ${ }^{16}$. En este proceso, Senghor simplifica: habla de lo africano como de un todo unitario y del negro como individuo singular. El procedimiento de vindicación es, también, extraordinariamente sencillo: consiste, fundamentalmente, en demostrar que es positivo el término negativo que se atribuye al negro. Si el estereotipo blanco dice que el negro es intuitivo, emocional, irracional, frente a la racionalidad europea, o, mejor aún, frente a la clarté filosófica francesa, Senghor procede a ponderar la emoción sobre la razón y a presentar la naturaleza emocional del negro como admirable, hermosa y superior: l'emotion est nègre comme la raison hellène. En este sentido, Senghor no construye un negro alternativo: simplemente asume el negro de los blancos y arguye su bondad ${ }^{17}$.

15 Según Moura [1997: 69-70] el movimiento de la Négritude se fundamentaría en una vitalidad espiritual que, mediante la poesía, se concede a lo que anteriormente se consideraba un estereotipo degradante; esto es, concede valor a todo lo que se consideraba negativo o inferior (el sufrimiento de los esclavos, el instinto y el misterio de Africa, la sensualidad e intuición precolonial, la percepción maternal del paisaje), celebra un lenguaje despreciado y rehabilita la expresión de las comunidades minoritarias (el créole, las lenguas francas, las variedades 'negras' de las lenguas metropolitanas). Cabría señalar que la búsqueda de una identidad mítica y antigua y la utilización identitaria de la literatura no son específicas de la Négritude, que comparte con los nacionalismos románticos europeos.

16 Senghor ha vuelto a menudo sobre el concepto de negritud. Además de algunos ensayos sobre sus «precursores» [SENGHOR, 1964: 407-411; 425-236], la exposición más clara de este concepto se encuentra, a mi juicio, en el tercer volumen de Liberté [SENGHOR, 1977: 11-18; 69-79], y, especialmente, en «Qu'est-ce que la négritude» [Senghor, 1977: 90-101], en la brevísima nota «La négritude debout» [Léopold Sedar Senghor, 1961: 197-199] y en «Réponse de Senghor a Césaire: La négritude comme culture des peuples noirs, ne saurait être dépassé» [1976: 49-69; vid. quoque SENGHOR, 1970: 179 ss.]. Sobre la poética senghoriana de la negritud, vid. KESTELOOT [1965: 110-114]; JAHN [1966/ 1971: 286 ss.; de LeUSSE, «La mission du poète: La négritude» [1967: 219-242]; Butler [1976: 342-350].

${ }^{17}$ La de Senghor es, por tanto, una estrategia de la inversión de valor: de ahí que defienda la idea de que los africanos se caracterizan por la razón intuitiva, y que, para contravenir la afirmación de que son seres emocionales sin capacidad de autocontrol, arguyera que, en efecto, son "criaturas de la emoción», seres puramente sensoriales, y que este estado de exacerbado sentimiento les permite el acceso a realidades superiores [SENGHOR, 1970: 184]. 
La negritud es también un proyecto político, inspirado en una versión del socialismo que quiere hibridarse con un presunto comunalismo idílico y ancestral africano: quiere presentarse, de este modo, como una combinación de valores tradicionales (o reconstruidos como tales) con valores socialistas, que se perciben como concomitantes o afines ${ }^{18}$. De este modo, la negritud podría también juzgarse como una utopía arcaica, como una suma de socialismo e indigenismo, que a la vez que se opone al modelo capitalista occidental, promueve valores espirituales y emocionales frente al presunto materialismo y racionalismo europeo. Este misticismo comunalista (que también se encuentra, por ejemplo, en la literatura de Rabindranath Tagore) y este proyecto político permitirían comparar fructíferamente la negritud con otros movimientos y, en especial, con los indigenismos latinoamericanos.

Hacia comienzos de los años cincuenta la negritud era ya un movimiento consolidado, cuyos planteamientos crearon un contexto que hizo posible replantear la práctica colonial e ideológica europea de forma radicalmente diversa. Un colaborador de Césaire, Michel Leiris, publicó entonces uno de los primeros análisis de las relaciones del imperio y la colonia (o de la ideología imperial) con una disciplina «científica», la etnografía ${ }^{19}$. El trabajo de Leiris abrió un debate que prosiguió con intensidad variable en las décadas siguientes, y que, en lo fundamental, se preguntaba hasta qué punto y de qué modo el deseo europeo de poder había determinado y conformado el conocimiento y los saberes europeos sobre el resto del planeta y hasta qué punto y de qué modo los escritores europeos - tanto de obras científicas como de obras literariasparticiparon vital e ideológicamente de las relaciones coloniales y neocoloniales. La pregunta de Leiris por la complicidad entre el saber y el poder imperial (a propósito, ciertamente, de la etnografía) reaparecerá en la obra de Edward Said, Orientalism (1978), como cuestión fundante a propósito de los saberes históricos y filológicos del orientalismo europeo. Leiris había glosado copiosamente una 'asimetría', a saber, el hecho de que los europeos, durante siglos, hubieran hablado por el resto del mundo mientras que lo inverso no era cierto, y profetizó que, en el futuro, hablarían y responderían los estudiados y observados, los objetos de ese discurso y de esas disciplinas y saberes. La primera

18 Así, por ejemplo, en la atribución utópica de reciprocidad, distribución y espíritu comunal a las relaciones sociales africanas. La relación entre negritud y socialismo es tema central del segundo volumen de Liberté de Senghor, subtitulado Nation et voie africaine du socialisme [1971]. Sobre la combinación de socialismo y tradicionalismo comunal, vid. CHILDS [1997: 39],

19 Michel Leiris, «L'ethnographe devant le colonialisme» (1950; rpt. 1966: 125-145]. Sobre la relación y la complicidad de colonialismo y antropología vid. Asad [1973: passim], CLIFFORD [1988], LECLERC [1972]. 
parte de esa afirmación - la del que no habla sobre sí, sino que es hablado o ficcionalizado- recurre en la obra de Edward Said y Gayatri Spivak; la segunda, esto es, la idea de la mirada devuelta, de la respuesta del colonizado, había comparecido de forma conspicua en el Orphée noir de Sartre y reaparecerá en los sesenta en su prólogo a Les damnés.

La obra de Fanon, que comienza a aparecer impresa en 1952, se escribe, pues, en un momento en el que la resistencia de Césaire, la negritud senghoriana, la vindicación órfica de Sartre, la escritura de Leiris (e incluso la de Mannoni) habían sentado nuevos términos para la reflexión crítica y comprehensiva sobre el hecho colonial ${ }^{20}$. El movimiento africano de la negritud acabaría por perder virulencia hacia el fin de la década de los sesenta, es decir, con los procesos de independencia política de varios países africanos. ${ }^{21}$ Cuando escribe Fanon, es aún un contexto y un punto de referencia necesario para la comprensión del hecho colonial.

Alienación Colonial y RePresentación literaria: Peau NoIre (1952)

j'accepte... j'accepte... entièrement, sans reserve ma race qu'aucune ablution d'hysope et de lys melés ne pourrait purifier ma race rongée de macule ma race raisin mur pour pieds ivres (Aimé Césaire, Cahier d'un retour au pays natal)

20 CHILDS [1997: 57] menciona dentro de un mismo grupo a Fanon y a Amílcar Cabral: salvo, secundariamente, en el artículo «A liberaçâo nacional e a cultura» (donde hay algunas ideas que recuerdan el nacionalismo cultural de Les damnés), no encuentro concomitancias apreciables entre ambos. AshCROFT et al. [1989: 153] tratan a Fanon en relación con el movimiento del Atlántico Negro (Black Atlantic) de C. L. R. James y Paul Gilroy y con la vindicación de la antillanité de Edouard Glissant. La relación con Glissant no está suficientemente demostrada: antes bien, por encima de la 'antillanidad' común, no hay muchas relaciones evidentes entre ambos. En cambio, los estudios del historiador marxista C. L. R. James (y especialmente The Black Jacobins, 1938) se publicaron antes de la eclosión del movimiento de la negritud y es posible que la investigación de su relación con Césaire, Fanon y Senghor fuera fructífera.

${ }^{21}$ La abierta censura del concepto senghoriano de negritud la inicia realmente Fanon, como quiero evidenciar aquí. No obstante, se considera que la crítica de la negritud comienza en los años setenta con los trabajos de MARCiEn Towa (Léopold Sédar Senghor: Négritude ou servitude, 1971) y Stanislas ADotevi (Négritude et négrologues, 1972) y con el congreso de Villetaneuse de 1973, Négritude africaine, négritude caraïbe. Cfr. Hausser [1982: 28ss, 67ss.]; ChEVRIER [1984: 45 ss.]. 
Peau noire es quizá la obra de Fanon que se presenta con una escritura menos abiertamente politizada y activista: de hecho, el libro se identifica, en principio, como un estudio clínico [1952: 10] que pretende «liberar al hombre de color de sí mismo», pero que, sobre todo, pretende, prioritariamente, proporcionar una interpretación psicoanalítica del problema negro, revelar las anomalías afectivas del edificio de complejos del negro, descubrir su proceso de alienación, su 'inferioridad' o, más bien, 'inferiorización' - por parte del blanco-y el proceso de interiorización de tal inferioridad ${ }^{22}$. No es éste, pues, un análisis de individuos, ni un análisis psicológico de lo singular, ya que la alienación del negro no es una cuestión individual, sino, sobre todo, una cuestión social: «disons qu'il s'agit ici d'un sociodiagnostic». El sociodiagnóstico implica un estudio de la posición $\longrightarrow$, mejor, de las diferentes posiciones- del negro ante la civilización blanca y de la naturaleza de sus actitudes; debe concluir con una explicación psicopatológica del existir del negro y debe comprender una reflexión sobre cómo éste indaga su propia identidad siendo así que, y ésta es una de las premisas fundantes de la obra, el alma negra es una construcción del blanco [1952: 7-11] ${ }^{23}$.

Fanon comienza el análisis de la alienación del colonizado con un examen de la enajenación lingüística: de su adopción del modelo «blanco» (y, en el ca-

22 El título original de la obra era «Ensayo sobre la desalienación de los negros». El análisis clínico de la colonización contaba con un precedente: dos años antes había aparecido La psychologie de la colonisation (1950) de Octave Mannoni, que no considera la literatura y el arte, y que, por ello, no trataré en estas páginas. Contra Mannoni se dirigen abiertamente muchas consideraciones de Fanon y, en especial, contra el entendimiento del dominio colonial por el complejo de inferioridad y dependencia del colonizado negro y el complejo civilizador del blanco. Véase la nota siguiente.

23 «La civilisation blanche, la culture européenne ont imposé au Noir une déviation existentielle. Nous monstrerons ailleurs que souvent ce qu'on appelle l'âme noire est une construction du Blanc» [FANON, 1952: 11]. Junto a estas tareas básicas, de naturaleza sociológica y psicológica, Fanon [1952: 67 ss.] realiza una crítica feroz de la Psychologie de la colonisation de Mannoni [1950] y de su concepto del complejo de Próspero en «Du prétendu complexe de dépendence du colonisé». Mannoni [1950: 71] había acuñado la expresión complejo de Próspero para referirse a un conjunto de disposiciones neuróticas inconscientes que designan a la vez «la figura del patemalismo colonial» $y$ «el retrato del racista cuya hija es objeto de un intento imaginario de violación por parte de un ser inferior». Próspero es un personaje de The Tempest de Shakespeare, junto con su hija Miranda y el salvaje Calibán: Mannoni utilizó la trama shakespeareana para explicar la situación colonial y, particularmente, la malgache. Posteriormente, la expresión complejo de Próspero llegaría a generalizarse (de hecho los editores de la traducción inglesa retitularon el libro como Prospero and Caliban) para referirse a una necesidad de dominación de origen infantil (partiendo de Mannoni, 1950: 87) o bien al deseo de afirmar la dominación sobre seres a los que se primitiviza, a los que se estima inferiores o a los que se trata como a tales: su contrapartida sería el complejo de dependencia del colonizado. Vid. MANNONI [1950: 71 ss., 105 ss.]; FANON [1952: 86 ss.] 
so antillano, del francés), del deseo del negro de mimetizar totalmente el acento y la lengua del colonizador, de la compulsión por convertirse, linguíisticamente, en un quasi-Blanc ( En France, on dit: parler comme un livre. En Martinique: parler comme un Blanc», 1952: 16), de la presunción -no expresade que es posible hacerse blanco (se blanchir) mediante el rechazo de todo lo asociado con lo negro, incluido el lenguaje (sea un lengua en particular o el creolismo, como fenómeno, en general) ${ }^{24}$. Es ésta la primera manifestación -entre otras muchas de una larga serie - de la idea del mimetismo del negro, que es recurrente en Peau noire. El negro que habla bien francés es un quasi blanco [1952: 16]; el antillano que pasa una temporada en la metrópolis intenta parecerse al blanco, adopta sus cosas, sus formas exteriores de civilidad, sus expresiones, y, en suma, pretende adquirir un sentimiento de igualdad con el europeo [1952: 20]; el negro, además, es apreciado en cuanto se asimila, o según el grado en el que se asimila, de ahí la tendencia a la reacción como conducta [1952: 29]. En la autobiografía novelada de (la antillana negra) Mayotte Capécia, Je suis Martiniquaise (1948), Fanon analiza el deseo de la protagonista de casarse con un blanco, los sueños en los que se blanquea mágicamente, sus delirios de que se convierte en un ángel «rose et blanche» [1952: 35, 41]. En la novela de René Maran, Un homme pareil aux autres (1947) estudia cómo el protagonista (negro), Jean Veneuse, siente que ha sido formado a imagen y semejanza de aquellos que le desprecian [1952: 52], a pesar de que aquellos que le estiman consideran que es «como nosotros» (como nosotros, pero no uno de nosotros), le insisten en que no es negro o que de negro no tiene más que la apariencia [1952: 56] ${ }^{25}$. Es decir, Fanon analiza cómo, desde el lenguaje a la ficción y a la autobiografía con un alto grado de ficción, se manifiesta y se tematiza el deseo de de-racialización, la aspiración del negro al mimetismo absoluto con el blanco y lo europeo.

No parece haberse advertido suficientemente que en Peau noire el instrumento de la alienación es, fundamentalmente, el de las representaciones: las revistas ilustradas y las ficciones para la infancia son, en particular, un ejemplo

24 Vid. el capitulo «Le Noir et le langage» [1952: $13 \mathrm{ss]} \mathrm{y,} \mathrm{especialmente,} \mathrm{las} \mathrm{formas} \mathrm{lin-}$ gǘsticas por las que el blanco «primitiviza» al negro (dirigiéndose a él como a un niño, hablando en petit-nègre, etc.). El deseo de se blanchir inspira también algunas de las páginas más interesantes de los estudios simétricos de «La femme de couleur et le Blanc» y «L'homme de couleur et la Blanche» [1952: $35 \mathrm{ss,} 53 \mathrm{ss}$.].

${ }^{25}$ La obra de Capécia proporciona, además, un modelo para concebir la relación entre la mujer negra y el blanco (con el odio de la negra a su color, su deseo de 'lactificarse' y aclarar la raza); la de Maran permite disponer de un ejemplo simétrico, en el que el hombre negro enamora a una mujer blanca para, de algún modo, convertirse en blanco. 
recurrente y significativo de la argumentación de Fanon. Las historias de Tarzán o de exploradores, las viñetas, tebeos y relatos han sido escritos por blancos para niños blancos: son los mismos relatos, señala Fanon, que leen con fruición los niños indígenas en las Antillas y, muy posiblemente, en el resto de las colonias. "Y el Lobo, el Diablo, el Genio Malo, el Mal, el Salvaje son siempre representados por un negro o un indio», y como siempre hay identificación con el vencedor, el niño negro se hace explorador, aventurero, misionero, y «corre el riesgo de que le coman los negros malos» del mismo modo que el niño blanco [1952: 119]. A los que sostienen que esto carece de importancia, replica Fanon que así se construye una imagen del negro y, sobre todo, que así construye el negro una imagen de sí. Ese niño negro es el mismo que, en la escuela, se refiere aplicadamente a nuestros ancestros galos, «nos pères les Gaulois» [1952: 120], y el mismo que se identifica con el explorador y el civilizador blanco. No es de extrañar, por tanto, que el joven de las Antillas manifieste una tendencia, o una actitud, totalmente blanca, o que piense y vea como un blanco: de hecho, en la escuela, lee historias de salvajes negros ${ }^{26}$. Por ello, el negro no se inferioriza: le inferiorizan. Advierte quizá más tarde la irrealidad de muchas proposiciones que había interiorizado y hecho suyas y que en realidad proceden de la actitud subjetiva del blanco. Sólo entonces comienza su verdadero aprendizaje de sí [1952: 122]. El negro, dice Fanon con metáfora repetida, endosa la librea que le ha hecho el blanco y que es la que aparece en las historias para niños, en la literatura o en el cine: por su parte, el blanco le hace negro insistentemente, desea encadenarlo a su imagen (l'attacher à son image) y fijarlo en ella [1952: 27, 92] ${ }^{27}$.

Las representaciones, las formaciones discursivas, construyen, en cierto modo, el mundo. Es una constelación de datos y una serie de proposiciones las que lenta e insidiosamente, mediante textos, revistas, cuentos, novelas, películas, libros escolares, programas de radio, van conformando la visión del mundo de la colectividad a la que se pertenece [Fanon, 1952: 124]. En el caso antillano, el individuo posee una visión del mundo que es blanca, porque, en efecto, se ha construido como blanca y a partir de representaciones

${ }^{26}$ De ahí también la paradoja antillana: «... l'Antillais ne se pense pas Noir; il se pense Antillais. Le nègre vit en Afrique. Subjectivement, intellectuelement, l'Antillais se comporte comme un Blanc. Or, c'est un nègre» [1952: 121].

27 A este respecto, véase la descripción de las fantasías de los que desean tener a blancos bajo sus órdenes 0 , en cualquier caso, hacer que los blancos tengan actitud de negros, entendidas como formas de vengarse de la imago [FANON, 1952: 49]. La misma idea de fijar a una imagen, encadenar o aprisionar en un estereotipo comparece a propósito de la naturaleza del discurso y las representaciones etnograficas, que 'encierran' al objeto descrito en sus costumbres [FANON, 1952: 76]. 
culturales blancas. ${ }^{28}$ Es más, hasta la aparición de Aimé Césaire y el movimiento de la negritud, ningún antillano «era capaz de concebirse a sí mismo como un negro», aun siéndolo realmente. Por ello, las representaciones ficticias, textuales, etc., son relevantes: procuran la identidad, la construcción de la imagen de sí, de la colectividad, de las relaciones. El factor más constante de alienación sería, precisamente, el hiato entre las representaciones y la aprehensión de su falsedad. De los muchos que aduce Fanon es representativo el caso de las redacciones de los antillanos de diez a catorce años, que, ante el tema «Impresiones antes de ir de vacaciones», responden como parisinos. Se encuentran en ellas observaciones como las siguientes: «j'aime les vacances, car je pourrai courir à travers les champs, respirer un bon air et je reviendrai les joues roses» [Fanon, 1952: 132 n. 25: cursiva del autor]. Esto es claro indicio, por una parte, del poder de arrastre de las convenciones de escritura impuestas escolarmente (o impuestas, en general, por una cultura); por otra, denuncia cuál es la representación de sí que se ha construido una colectividad.

Puede entenderse que la obra de Fanon propone una moraleja recurrente: el antillano desconoce íntimamente que es un negro, y este hecho particular corrobora, en el plano general, la proposición más relevante aún de que la percepción se sitúa siempre en el plano de lo imaginario. Estas reflexiones permiten enlazar con las observaciones de Sartre sobre el antisemitismo, del que Fanon extrae una continua inspiración acerca de la representación simbólica racista ${ }^{29}$.

En el plano simbólico, el negro es el símbolo del mal o de la fealdad, pues hay un maniqueísmo «delirante» en la representación del blanco y del negro [Fanon, 1952: 145, 148]. En Europa «el Mal está representado por el Negro»: el verdugo es negro, Satán es negro, lo sucio es lo negro - tanto en el plano físico como el moral - y hay muchas expresiones que hacen negro el pecado. El negro representa, simbólicamente, el lado malvado de la personalidad, el arquetipo de los valores inferiores. Lo negro sirve para las pulsiones más inmorales y para los deseos más inconfesables. Por ello, no es de extrañar que el negro antillano padezca negrofobia, ya que, cultural, simbólica, representativamente, comparte obsesiones, imágenes y prejuicios, con el blanco. Fanon, pues, invalida la noción junguiana de inconsciente colectivo, que reduce a una simple imposición cultural generada por un conjunto de mitos, imágenes y representaciones. Si el negro comparte con el blanco este presunto inconsciente es porque

28 Véase la descripción de las reacciones del público francés y antillano a la proyección de las películas de Tarzán en FANON [1952: 124 n. 15].

29 Para el uso extensivo tácito o expreso de las Réflexions sur la question juive de Sartre, remito a FANON [1952: 70, 95, 130, 146-147]. 
comparte un conjunto de imposiciones culturales en las que el negro simboliza lo negativo. El negro antillano es negrófobo porque ha sido educado con representaciones que le imponen, en cierto modo, serlo: «je me méfie de ce qui est noir en moi, c'est-à-dire de la totalité de mon être» [1952: 155].

$\mathrm{O}$, en otros términos: leemos libros blancos. «Nous lisons livres blancs et nous assimilons petit à petit les préjugés, les mythes, le folklore qui nous viennent d'Europe... il me serait facile de montrer que le nègre, irréflexivement, se choisit objet susceptible de porter le péché originel. Pour ce rôle, le Blanc choisit le Noir, et le Noir qui est un Blanc choisit aussi le Noir. Le Noir antillais est esclave de cette imposition culturelle» [1952: 155]. En los términos clínicos en los que Fanon quiere impostar su obra, reside aquí la ambigüedad neurótica en la que vive el negro y de aquí, de hecho, extrae las premisas de la psicopatología que Peau noire se ha propuesto trazar.

Este conjunto de observaciones parece centrarse en lo que Fanon llama a veces la imago, o, en ocasiones dispersas, la tematización [1952: 91]: en lo que cifra en la metáfora de la librea, en lo que, en ocasiones nombra mito [1952: 94], formación de una imagen, o, también ocasionalmente y tomando los términos de un pasaje de Sartre (de las Réflexions sur la question juive), representación fijada (représentation fixé) [cfr. 1952: 93]. Peau noire no se limita al sociodiagnóstico de tales temas, imágenes y representaciones o, mejor aún, al sociodiagnóstico de la alienación del negro a través de las nociones de mimetismo, imagen, escisión y autorrepresentación: quiere ser también una obra militante, agente de la des-alienación, de vindicación y conciencia. Esto no implica, sin embargo, la adhesión de Fanon a los presupuestos de la négritude formulados por Léopold Senghor, que, a la representación creada por el blanco -al negro como símbolo de irracionalidad, animalidad, maldad, etc.- opone realmente una contra-representación, una imagen pendular, a saber, aquella que reivindica para si -y rehabilita - los aspectos que en la oposición maniquea diagnosticada por Fanon se identifican con lo negro. El Negro de la Negritud y el Negro del Blanco se reúnen por tanto bajo las mismas premisas ${ }^{30}$.

${ }^{30}$ Fanon comenta la afirmación de L. Senghor de que el negro posee una sensibilidad emotiva (el famoso motto «l'émotion est nègre comme la raison hellène») que parece una inversión vindicativa del estereotipo blanco sobre la irracionalidad negra pero que, en realidad, lo sanciona. El Negro senghoriano es también un estereotipo que Fanon desautoriza mediante la reescritura paródica: «Et voici le nègre réhabilité..., gouvernant le monde de son intuition, le nègre retrouvé, ramassé, revendiqué, assumé, et c'est un nègre, non pas, ce n'est point un nègre, mais le negre, alertant les antennes fécondes du monde... Je suis le monde!» [1952: 103; cursiva mía]. El negro sensitivo, como poète du monde, en comunión con el mundo, es figura central de los Chants d'ombre de Senghor (1945) y aflora a menudo, de forma celebratoria, en los primeros escritos de Sartre. 
Es evidente que podría analizarse igualmente y con las mismas armas la construcción de la imagen del negro por parte de los blancos y para los blancos (al igual que la contrarrepresentación de la imagen del negro del movimiento de la Negritud): no obstante, Fanon está particularmente interesado por el problema específico del negro ante una representación de sí como el otro (lacaniano) y los resultados de alienación, escisión de conciencia, mimetismo de lo blanco, vindicación o complejo que comporta tal representación. Las pocas alusiones a la imagen que el blanco crea del negro para sí inciden en la difusión de obras literarias, como por ejemplo, en el poder de La cabaña del tío Tom, en medios francófonos, para realizar la evocación del negro [1952: 140] ${ }^{31}$; o bien en la representatividad de los estereotipos de las ficciones sobre los negros que establecen relaciones amorosas con mujeres blancas (Deep are the Roots, Strange Fruit: vid. Fanon, 1952: 142); o bien, y sobre todo, en la genitalidad de la imagen del negro, que es, a menudo, pero siempre en el plano imaginario o en el nivel paralógico, la representación del instinto sexual y del poder genital ${ }^{32}$.

A pesar de la continua invocación del instrumentario del psicoanálisis europeo en las páginas de Peau noire, el modelo ideológico del libro se encuentra, a mi juicio, en las reflexiones de Jean-Paul Sartre sobre la cuestión judía -como ya ha habido ocasión de indicar- que se reaplican, a menudo, y con mínimas transposiciones, para explicar la percepción racista del negro. Sartre, además, había publicado ya el ensayo Orphée noir, que había precedido la antología de la poesía negra y malgache de Senghor, y que se había convertido en referencia necesaria en la discusión de la negritud. Sartre, por último, como autor de $Q u$ 'est-ce que la littérature?, había propuesto unas tesis sobre la escritura comprometida que satisficieron particularmente a Fanon. De Sartre proceden, secundariamente, algunas reflexiones sobre la negritud y el marxismo o sobre la posible asimilación del negro y el proletario ${ }^{33}$. De hecho, Fanon considera que Orphée noir es un de los hitos más relevantes en la «intelectualización del existir del negro», a pesar del triunfalismo de Sartre en su gloriosa visión de ese negro que recoge la antorcha del élan poétique de la humanidad, ${ }^{34} \mathrm{y}$, sobre todo, a pesar de que Sartre también

31 Vid. quoque FANON [1952: 161], acerca de la formación sobre «cómo ver un negro» adquirida en Un capitán de quince años, Los viajes de Livingstone y las novelas de aventuras coloniales.

32 Sobre la genitalización de la imagen del negro -que es también una forma de asimilarlo a los animales- vid. FANON [1952: 126-129, 133, 137, 143-146].

33 V. especialmente FANON [1952: 108-109, 139, 148-150].

34 Léase, por ejemplo, en Sartre: «à chaque époque, les circonstances de l'histoire élisent une nation, une race, une classe pour reprendre le flambeau, en creant des situations qui ne peuvent s'exprimer ou se dépasser que par la Poésie; et tantôt l'élan poétique coïncide avec l'élan révolutionnaire et tantôt ils divergent» [Orphée noir, 29]. Sartre saluda la gran «ocasión histórica» de coincidencia del espíritu revolucionario y del poético en la poesía negra. 
construye un negro al que asigna una tarea preexistente y, por tanto, le priva de iniciativa y de capacidad agente. ${ }^{35}$ Fanon objeta y censura la homogeneidad y escasa atención a las peculiaridades diferenciales entre negro y negro - basta ser negro, aunque se sea antillano, senegalés o malgache- del Sartre de la Anthologie; y no es necesario hilar muy fino para descubrir un abierto reproche a Sartre en la vaga formulación impersonal de su crítica a la nueva construcción del negro: «et l'on est venu l'helleniser, l'orphéiser» [1952: 150 ${ }^{36}$. O podría decirse, en otros términos, a construirlo con paradigmas también europeos, a «dignificarlo» con el modelo órfico.

Más ambigua es la posición de Fanon ante la asimilación entre marxismo y vindicación racial o entre marxismo y negritud. Senghor y Sartre -quizá inspirándose lejanamente en Aimé Césaire o, más bien, en una peculiar e idiosincrásica interpretación de Césaire- habían propuesto una identificación estricta entre el negro y el proletario: para Césaire el blanco simbolizaba el capital como el negro simbolizaba el trabajo y, por ello, cuando cantaba la lucha de los negros decía cantar la lucha del proletariado mundial ${ }^{37}$. Sartre, que cita esta afirmación en Orfeo Negro, apostilla que los cantores más ardientes de la negritud son también, al mismo tiempo, activos militantes marxistas, a pesar de que la idea de raza no siga, como es evidente, las pautas de la idea de clase. Es más, la negritud (senghoriana) podría entenderse como la antítesis de una progresión dialéctica. La afirmación teórica y práctica de la supremacía del blanco es la tesis; la posición de la negritud como valor antitético es el momento de negación: debería así prepararse el momento de síntesis, que, según Sartre, sería la realización plena del ser humano en una sociedad sin razas (Orphée, 30). De este modo, la Negritud habría de destruirse: es un paso - y nunca la culminación-, es un medio, pero no un fin. Del mismo modo, la poesía de la negritud estaría teñida de esta tensión dialéctica y de esta dinámica histórica [vid. Fanon, 1952: 107, 159].

35 Véase, por ejemplo, la acidez de la crítica de Fanon a la tarea histórica que Sartre concede a la poesía negra y al negro en general: «Et voilà, ce n'est pas moi qui me crée un sens, mais c'est le sens qui était là, pré-existant, m'attendant. Ce n'est pas avec ma misère de mauvais nègre, mes dents de mauvais nègre, ma faim de mauvais nègre. que je modele un flambeau... afin d'incendier ce monde, mais c'est le flambeau qui était la, attendant cette chance historique» [Fanon, 1952: 109; cursiva mía].

36 Sartre parece haber sido sensible a esta crítica: la reproduce él mismo en el prólogo de 1961 a Les damnés de la terre: «Europa creyó en su misión: había helenizado a los asiáticos, había creado esa especie nueva, los negros grecolatinos" [1961: 7].

37 Aimé Césaire fue un activo militante comunista durante los años treinta. Su ruptura con el Partido Comunista Francés y la denuncia de su complicidad colonial es el tema de la Lettre à Maurice Thorez (1956), que apareció sólo un año después de su Discours sur le colonialisme (1955). 
Frente al marxismo de los negros buenos, Fanon parece aprobar abiertamente la idea - a su juicio decisiva — de que la literatura ha de comprometerse en la tarea actual de llevar a la colectividad hacia la reflexión y la mediación [Fanon, 1952: 148]: debería también, en el curso de esa tarea, levantar una suerte de «espejo» en el que podría al fin el negro reencontrarse a sí mismo en el proceso de des-alienación. La propuesta sartriana de $Q u^{\prime}$ est-ce que la littérature?, y más particularmente, la tesis de la acción de la literatura sobre la colectividad en términos de conciencia es la que vertebra Peau noire en lo que se refiere a las representaciones literarias: la adopción de esta tesis es una enunciación del deber ser de la literatura en general y de la literatura negra en particular (frente a la antorcha ardiente y el triunfalismo histórico del mismo Sartre o el Supernegro de Léopold Senghor). La de Fanon es, en cambio, una reflexión sobre las representaciones literarias y sobre la función de la literatura en la formación de la conciencia de sí del colonizado.

Este recurso a la literatura como instrumento (o a la idea sartriana de la literatura) se comprende más cabalmente si se repara en que para cumplir el propósito de la des-alienación, de la construcción de la conciencia de sí, no basta el psicoanálisis. En Peau noire, Fanon lleva a cabo una acerba crítica de Lacan [1952: 65], comenta que «ni Freud, ni Adler, ni siquiera el cósmico Jung han pensado en los negros durante su investigación» [1952: 123], censura abiertamente la noción lacaniana del stade du miroir [1952: 131 n. 25] y, como ya se ha dicho, la noción junguiana de arquetipo, que le conduciría a admitir la universalidad de las estructuras psíquicas que Fanon cree culturales y a conceder que los temores íntimos ante lo negro se sitúan en el inconsciente colectivo, es decir, en la sustancia cerebral heredada. Ahora bien: Jung atribuye al inconsciente colectivo un conjunto de actitudes colectivas de un grupo muy determinado [1952: 151-152], de tal modo que, al buscar la juventud del mundo, se queda varado en la juventud de Europa. O, en otros términos, el arquetipo queda reducido, en la crítica de Fanon, a un mero estereotipo cultural y el inconsciente colectivo a un conjunto de representaciones ${ }^{38}$.

Peau noire entraña una concepción de la literatura en términos morales, psicologicos y políticos: esto es, en tanto que instrumento -con otros muchos- que levanta imágenes y representaciones, y, por tanto, coadyuva a la

38 Jung habría asimilado regularmente lo extranjero con la oscuridad. En Europa, según Fanon, el negro tiene una función básica, que es la de representar los sentimientos inferiores, las inclinaciones censurables, el lado oscuro del alma [1952: 154]. El inconsciente colectivo no es una herencia cerebral universal, sino una imposición cultural europea. Otras observaciones sobre el inconsciente colectivo en FANON [1952: 74]. Sobre la noción de imposición cultural, vid. FANON [1952: 154-155, 157]. 
formación de la conciencia y a la construcción de la identidad de los representados. Por ello, contribuye decisivamente a la percepción del mundo del sujeto. Del mismo modo, por tanto, es instrumento de alienación y puede serlo (y aquí afloraría cabalmente el ideal sartriano de literatura) de des-alienación. La apreciación de la literatura se produce siempre al englobarla dentro de un conjunto mayor de estrategias textuales y de representaciones: es o puede ser uno de los elementos de la imposición cultural, de la fabricación de los estereotipos (que sustituyen, de facto, al arquetipo y al inconsciente colectivo junguiano), o un vehículo del mimetismo del colonizado. Los ejemplos literarios, que son muchos en Peau noire, están siempre al servicio del análisis de la representación y de la imagen.

RESISTENCIA TEXTUAL Y NUEVAS LITERATURAS NACIONALES:

LES DAMNES DE LA TERRE (1961)

A diferencia de Peau Noire, Les damnés de la terre (1961) es una obra abiertamente militante: es un «libro escandaloso» [Sartre, 1961: 9], dirigido a los colonizados y escrito en tono panfletario y agitador. Es una obra activista, revolucionaria - en el sentido fuerte que tenía esta palabra en los años sesenta-y redactada en plena efervescencia del conflicto argelino. Si Peau noire trataba acerca de la colonización en su dimensión simbólica, moral, psicológica y afectiva, esto es, trataba de la representación, de la imagen, de la identidad y la alienación y se presentaba como estudio clínico, Les damnés es una obra violenta, tanto verbalmente como por las actitudes también violentas que propone al colonizado en la víspera de la independencia, y está trufada -como el prefacio de Sartre- de obvias consignas políticas. A la violencia colonial opone la violencia de la descolonización ${ }^{39}$. De hecho, Fanon —en el plano político- se ha identificado con la defensa de la resistencia violenta y armada. Ahora bien, Les damnés es, además, una larga reflexión sobre la idea de nación -de nación joven, salida del proceso de descolonización--, de sentimiento nacional y, sobre todo, de cultura y de literatura nacional. De esta cultura nacional importa, fundamentalmente, su función en el proceso liberatorio: si se estima, como en efecto hace Fanon, que la estrategia imperial pasa por la eliminación de las cul-

39 De hecho, el capítulo inaugural del libro se dedica a la violencia [FANON, 1961/1986: 30 98]. Véase también la tesis de la violencia necesaria en el prólogo de Sartre [1961: 23-25], que plantea la utilidad del libro para extirpar el «colono que vive en cada uno de nosotros» y para mostrar que no hay ningún valor europeo que, visto de cerca, no esté «manchado de sangre». 
turas indígenas y, especialmente, por la supresión del proceso de identificación del indígena con un pasado culturalmente rico y diverso, la construcción de una literatura nacional y la recuperación de una cultura nacional y de una historia también nacional formarían parte del movimiento de resistencia.

El ensayo de Fanon adolece en este punto de una notable ingenuidad en el tratamiento de la idea de nación, nacionalismo y cultura nacional: en primer lugar, porque considera la idea de nación como dada o, mejor, considera que la nación constituye una realidad incontestable y permanente. Podría censurársele que su deseo de dotar de una fuerte idea de cultura nacional a las áreas «nacionalizadas» no deja de ser una imitación de la metrópolis —ordenada en naciones estado - y una nueva forma de mimetizar al blanco o, como él mismo habría podido decir en Peau noire, de se blanchir y hacerse quasi-Blanc. Por otra parte, la idea de cultura -que incluye todas las obras de creación, incluidas las literarias - depende muy estrechamente, en el libro de Fanon, de la nación-estado, sin la que no es concebible ${ }^{40}$.

Aunque aquí interesan únicamente las implicaciones literarias y, en general, culturales, del libro de Fanon, conviene adelantar que la totalidad del libro acusa un nacionalismo extremo y que contiene una aprobación entusiasta y celebratoria del valor de la nación para los colonizados y ex-colonizados. La idea de nación preside idealmente - y contradictoriamente- el libro de Les damnés ${ }^{41}$. De hecho, Fanon identifica la liberación nacional con el renacimiento nacional y todo ello con la «restitución de la nación al pueblo» [1961: 30]. La impostación general del libro se quiere, no obstante, marxista, a pesar de que Fanon sostiene en repetidas ocasiones que el marxismo debe modificarse para adecuarse a la naturaleza de los fenómenos coloniales ${ }^{42}$.

${ }^{40}$ La vinculación entre los movimientos y partidos de liberación e independencia y la idea de nación es también evidente en el prólogo de Jean-Paul Sartre, que había jaleado a aquel colonizado que, tras la descolonización y, eventualmente, tras haber matado al blanco, «por primera vez siente un suelo nacional bajo sus pies. En ese instante, la Nación no se aleja de él... se confunde con su libertad» [SARTRE, 1961: 20-21, cursiva mía].

${ }^{41}$ En Peau noire, la cuestión nacional había aflorado sólo ocasionalmente. Paradójicamente, una de sus apariciones más conspicuas es para criticar a Sartre que, en Orphée noir, había dejado a un lado las características «nacionales» de la literatura negra y colonial, a la que había tratado como un todo único e indistinto [1952: 139]. Sobre la relación entre la raza, la nación metropolitana y la nación postcolonial, Fanon había hecho algunas reflexiones fugaces [1952: 140, 164], si bien en aquella ocasión reconocía que el intelectual colonizado pertenece verdaderamente a la nación colonizadora: "Qu' est-ce que cette histoire de peuple noir, de nationalité nègre? Je suis Français. Je suis intéressé à la culture française, à la civilization française, au peuple français... Je suis intéressé personnellement au destin français, aux valeurs françaises, à la nation française...» [1952: 164; cursiva mía].

42 Tal modificación se debe fundamentalmente a la aparición de la idea de raza: «En las colonias, la infraestructura es también una superestructura. La causa es la consecuencia: se es rico por- 
En el uso de la idea de nación es evidente una notabilísima simplificación del caso europeo. Fanon deja sobreentender que la formación de las naciones europeas constituyó un proceso armonioso y homogéneo, regular y uniforme, fundado sobre el respeto mutuo de las entidades nacionales o estatales y que, frente a esta visión idílica (que el caso de la independencia de Irlanda, o del desmembramiento del imperio austro-húngaro, o de la redistribución del mapa europeo tras la segunda guerra mundial - con la creación de nuevas naciones y la total desaparición de algunas otras - bastaría para invalidar) ${ }^{43}$, la «formación nacional de las naciones subdesarrolladas» se percibe como un proceso agónico y radicalmente nuevo.

La reflexión sobre el proceso de formación nacional se articula en tres partes. La primera esta dedicada a describir el nacimiento de los partidos y movimientos nacionalistas y la formación de conciencias nacionales en las colonias y ex-colonias, todo ello en el contexto del proceso social de independencia y descolonización o, si se prefiere, en la transición singular del individuo de colonizado a ciudadano de una nación soberana e independiente [Fanon, 1961: 99-135]. La segunda está enteramente dedicada a la idea de conciencia nacional [1961: 136-187], al análisis de la conducta de la «burguesía nacional» en el período que sigue inmediatamente a la independencia y a la formación y desintegración de partidos y líderes nacionales. Por último, la tercera, que es la más que interesa en este lugar, está destinada enteramente al estudio de la cultura nacional y, por tanto, a la formación de una escritura y de una literatura nacionales en el proceso de la independencia y en el inmediatamente posterior [1961: 188-227]. En ningún momento de esta argumentación, sin embargo, parece plantearse Fanon la validez del concepto de nación o conciencia nacional cuando se aplica a territorios colonizados por las potencias europeas: diagnostica simplemente una debilidad de la conciencia nacional en los países subde-

que se es blanco y se es blanco porque se es rico. Por eso los análisis marxistas deben modificarse ligeramente siempre que se aborda el sistema colonial. Hasta el concepto de sociedad precapitalista, bien estudiado por Marx, tendría que ser reformulado... No son ni las fábricas, ni las propiedades... lo que caracteriza la clase dirigente. La especie dirigente es, antes que nada, la que viene de afuera» [1961: 34-35]. Además, el proletariado colonial, frente al europeo, formaría una clase casi privilegiada y, sobre todo, mimada por el régimen, de tal modo que sólo las masas rurales (concebidas como un freno revolucionario en el contexto metropolitano) se convierten en masas revolucionarias [1961: 101-103]. No es ya pues el obrero, sino el colonizado, el que encama al verdadero Proletario.

43 Véase por ejemplo, la observación siguiente: «En Europa, con excepción de ciertos matices (Inglaterra, por ejemplo, había cobrado cierto adelanto) los diferentes Estados en el momento en el que se realizaba la unidad nacional conocían una situación económica más o menos uniforme. Realmente ninguna nación, por los caracteres de su desarrollo y de su evolución insultaba a las demásm [FANON, 1961: 88]. 
sarrollados [1961: 136]; excluye que el anticolonialismo pueda adoptar una forma que no sea la del nacionalismo [ibid.] y lamenta - y al lamentar deja ver sus aspiraciones- que la conciencia nacional no sea, en la situación postcolonial, la «cristalización coordinada de las aspiraciones más íntimas de la totalidad del pueblo» o «el producto inmediato más palpable de la movilización popular». Esta idea integrista - y teleológica - de la conciencia nacional va pareja a la valoración de la «unidad nacional» como bien indiscutible y a la oposición neta y binaria del imperio (término negativo) y la nación (término positivo).

El estudio de la escritura y la literatura depende estrechamente de la vinculación entre cultura y nación. Fanon, de hecho, aunque define la cultura con extraordinaria vaguedad, lo hace siempre en términos de nacionalidad: «toda cultura es primero nacional» [1961: 197]; la cultura es «la expresión de una nación» [1961: 224; cursiva mía]; señala también, circularmente, que «la nación asegurará a la cultura las condiciones, el marco de expresión» [ibid.] e indica que «la nación reúne para la cultura los distintos elementos indispensables, los únicos que pueden conferirle credibilidad, validez, dinamismo, creatividad». También a esa condición nacional se le debe que la cultura sea "permeable a las demás culturas» y que influya sobre ellas [ibid.] ${ }^{44}$. Su entendimiento del hecho literario está incardinado, total y absolutamente, en la idea de resistencia cultural o textual -ante la metrópoli, ante la cultura del colonizador-y en la reivindicación de una cultura nacional con el instrumento de la fícción literaria ${ }^{45}$; se formula, en todos los casos, en términos agónicos y con profusión de metáforas bélicas.

Fanon aborda en primer lugar la recuperación de la historia: relata el deseo de buscar una cultura nacional pasada, anterior a la etapa colonial, que pueda «rehabilitar» al escritor y, en general, al colonizado [1961: 191]. No

44 Véase también: «Luchar por la cultura nacional es, en primer lugar, luchar por la liberación de la nación, matriz material a partir de la cual resulta posible la cultura» [FANON, 1961: 214]; «si la cultura es la manifestación de la conciencia nacional, no vacilaría en afirmar... que la conciencia nacional es la forma más elaborada de cultura» [1961: 226].

45 Vid. por ejemplo FANON [1961: 190] donde habla del campo de batalla cultural -paralelo al campo de batalla real de la descolonización violenta. El intelectual y el escritor colonizado se caracterizarían por buscar la cultura nacional poniendo distancia «con la cultura occidental, en la que corren el peligro de sumergirse» [1961: 191]. Sus ataques más acerbos están dirigidos contra el intelectual o el escritor que se ha dejado seducir por la cultura de la metrópoli y de la nación colonizadora, que intenta «hacer suya la cultura europea» [1961: 200] o se hace cómplice de escritores metropolitanos [1961: 201]. Es conspicuo el paralelismo de estos llamamientos con los de otros nacionalismos políticos, así como la responsabilidad que se concede a los intelectuales en la construcción de la nación. 
parece considerar el peligro de construir idílicamente un pasado ad hoc (como sucedió en algunos nacionalismos europeos), antes bien, da por supuesto que el hallazgo de un pasado que se representa como glorioso, hermoso, brillante o, al menos, solemne, $y$, sin duda, embellecido por sus propios deseos, devolverá al colonizado la dignidad y el equilibrio psicoafectivo, La recuperación del pasado precolonial adopta tonos extremadamente líricos: es un contacto con la «savia más antigua»; el descubrimiento de tal pasado está alentado por una «esperanza secreta», que es la de hallar una era «hermosa y resplandeciente», ya que es imposible, para el escritor o intelectual, «enamorarse» de la historia presente de un pueblo oprimido. El pasado es dignidad, gloria, solemnidad: se concibe ya como un pasado nacional y como una "cultura nacional pasada», sin preguntarse por la existencia misma del concepto de nación con anterioridad a la dominación colonial o sin considerar tan siquiera la hipótesis de que, aun aceptando la existencia de naciones propiamente dichas, éstas siguieran la distribución cultural, territorial, lingüística, étnica o religiosa de las naciones surgidas de la descolonización, cuyas fronteras, en la mayoría de los casos, fueron trazadas con cartabón y escuadra. Ese pasado nacional redescubierto o recuperado sirve especiosamente para fundamentar una «cultura nacional futura»: su exhumación es también una tarea agónica, ya que se estima que una de las tareas del colonizador es, precisamente, la de distorsionar, aniquilar y obliterar el pasado del pueblo oprimido; en otros términos, la eliminación del pasado y de la cultura pasada del colonizado es uno de los instrumentos de su enajenación cultural [Fanon, 1961: 192] ${ }^{46}$. De este modo, «el deterioro de la realidad nacional y la agonía de la cultura nacional mantienen relaciones de dependencia recíproca» [1961: 218]

La posición de Fanon contrasta con las ambiciones totalizadoras del panafricanismo o continentalismo, que, a su juicio, son simplemente una reacción que sigue las líneas del ataque colonial: esto es, si para el colonizador «el negro es un salvaje», tal negro no es angoleño ni nigeriano, sino sólo negro. Como reacción, también la condena del colonialismo se hace continental y tiende a afirmar la cultura africana en su totalidad o como unidad. Si el colonialismo no pierde el tiempo en negar una a una las culturas de las diferentes naciones (entiéndase, precoloniales), la respuesta del colonizado

46 El colonialismo habría convencido a los indígenas de que «venía a arrancarlos de la noche» y de que la partida del colono supondría una vuelta a la barbarie [FANON, 1961: 192]. Es más, «el dominio colonial, por ser total y simplificador, tiende de inmediato a desintegrar de manera espectacular la existencia cultural del pueblo sometido"; pretende hacer confesar al colonizado «la inferioridad de su cultura» e incluso convencerle de «la irrealidad de su nación» [1961: 216-217]. 
tenderá a ser, al menos de entrada, también continental: de este modo, afirma, «la literatura colonizada de los últimos veinte años [en Africa] no es una literatura nacional, sino una literatura de negros» [Fanon, 1961: 194]. Fanon explicaría así el surgimiento del movimiento literario de la négritude, que opone - cultural y literariamente- Europa a Africa como totalidades y unidades y como anverso y reverso de actitudes vitales y de estilos (esto es, como lo viejo a lo nuevo, la razón a la poesía, la lógica opresiva a la naturaleza desbordada, el escepticismo a la ingenuidad, la ceremonia a la libertad y la exuberancia, etc.). Ahora bien, prescindir de la idea nacional en cultura y literatura conduce, a su juicio, a un callejón sin salida [1961: , 194, 196-197].

Como contrapartida de la tendencia panafricanista, Fanon opone su tesis de las tres fases de la escritura colonial, que culminan en la creación de una literatura nacional propiamente dicha. En la primera fase, el escritor colonizado intenta probar que ha asimilado la cultura del ocupante y sus obras se corresponden, realmente, con las metropolitanas, hasta el punto de que podrían periodizarse como las de la literatura europea. Este sería el período asimilacionista integral. En un segundo momento, el colonizado decide realizar una inmersión o «reinmersión» en el pueblo, pero, como está separado culturalmente de él, se contenta con recordar: surge así una literatura de la memoria, de la vivencia infantil, de las leyendas reinterpretadas con una estética ajena. Es también una «literatura del malestar» ${ }^{47}$. Por último, llegaría un período «de lucha», en el que el escritor parece transformarse, literalmente, en una suerte de agitador con una «misión» que Fanon describe teleológicamente como «histórica» (e incluso formulando la idea, tan familiar, por cierto, a los españoles, de la nación como una «comunidad de destino»): debe sacudir y despertar al pueblo en vez de favorecer su letargo. Es ésta la que, en apretadas aposiciones, se describe como «literatura de combate, literatura revolucionaria, literatura nacional». Incluso como una literatura del espontaneísmo: los hombres y mujeres que «antes no habian pensado jamás en hacer una obra literaria» se encuentran ahora en situaciones excepcionales y lite-

${ }^{47}$ Fanon se había ya referido a la naturaleza del estilo y los temas del intelectual a punto de liberarse: menciona (de forma imprecisa) una literatura de grandes logros estilísticos pero temáticamente agotada. El estilo «estaría lleno de contrastes y de imágenes», sería «nervioso», extraordinariamente rítmico, eruptivo y violento [sic]: sería la traducción verbal de un cuerpo a cuerpo del escritor consigo mismo, de un combate con una parte de sí. No obstante, el camino del reencuentro con lo cotidiano sería infecundo, porque el escritor acabaría cantando los pormenores más triviales de lo autóctono [FANON, 1961: 200-201]. 
ralmente «sienten la necesidad de expresar su nación» y de convertirse en "portavoces de una nueva realidad en acción» [1961: 203] ${ }^{48}$.

El escritor colonizado no se daría cuenta, inicialmente, de que utiliza unas técnicas y, sobre todo, una lengua, tomadas del ocupante: se contentaría únicamente con revestir tales instrumentos con «un tono nacional» (si bien Fanon no indica en qué consiste esa tarea) pero que cae en la farsa del exotismo. Tras el asimilacionismo, sigue la poesía analítica y descriptiva, pero describir literariamente al pueblo no bastaría para hacer literatura nacional. Esta culminación elusiva, esa idea de literatura nacional, escapa siempre a la descripción. Fanon parece aproximarse a ella, primeramente, mediante negaciones: no es ni descripción, ni exotismo, ni ficcionalización anticuaria del pasado, ni mera memoria. En segundo lugar, dando por supuesta la comprensión inmediata de los términos implicados y de su combinación. Por último, eludiendo su caracterización mediante la propuesta de un caso ejemplar en el que, presuntamente, se hallaría una cristalización «de la voluntad popular»: se trata del poema Amanecer africano de Keita Fodeba. Posteriormente, esa literatura de combate se caracteriza vagamente por su poder de apelación y de conformación moral («convoca a todo un pueblo a la lucha por la existencia nacional», «informa la conciencia nacional», a la que «abre nuevas perspectivas», etc.: vid. Fanon, 1961: 220).

En un punto intermedio de este proceso se situaría el momento de mayor tensión y conflicto, el que precede a la explosión violenta de los movimientos anticoloniales y a la lucha de independencia: es el momento de la superproducción literaria, cuando los intelectuales se harían más productivos y eficaces. Abordarán entonces el género poético y trágico y sólo después cultivarán la novela, el cuen-

$48 \mathrm{La}$ analogía de este proceso con las tres etapas que había dispuesto Mariátegui en «El proceso de la literatura» (en Siete ensayos de interpretación de la realidad peruana, 1927) no es más que aparente. Mariátegui decía identificar un proceso que comenzaba en la literatura colonial, seguía con un período cosmopolita (en el que se asimilan elementos de otras literaturas) y culminaba con un periodo nacional. El sentimiento de lo autóctono proporcionaría la necesaria emancipación literaria. La condena del exotismo y la celebración del indigenismo convivían no obstante con un racismo indisimulado: el valor del indio se establece a costa del criollo y del mestizo, y, sobre todo, a costa de la depreciación extrema de lo que negros y orientales pudieran aportar a la literatura peruana «nacional» (e.g., el negro es un elemento colonial, wha mirado siempre con hostilidad y desconfianza la sierra.... Cuando se ha mezclado al indio ha sido para bastardearlo comunicándole su domesticidad zalamera y su psicología exteriorizante y mórbida...» [MARIÁTEGU, 1927/1996: XVII]; «...el chino... parece haber inoculado en su descendencia el fatalismo, la apatía, las taras del oriente decrépito»; «el aporte del negro... aparece más nulo y negativo aún. El negro trajo su sensualidad, su superstición, su primitivismo. No estaba en condiciones de contribuir a la creación de una cultura, sino más bien de estorbarla con el crudo y viviente influjo de su barbarie» [ibid.; cursiva mía]. 
to y el ensayo. De este modo, hasta la opción entre géneros parece depender, en la situación postcolonial, del estadio de la lucha de liberación: Fanon habla incluso de una ley de expresión según la cual las manifestaciones líricas comienzan a escasear a medida que se precisan «los objetivos y los métodos de la lucha de liberación». Seguiría después una literatura de consigna y una «cristalización de la conciencia nacional» que transforma los géneros y los temas literarios y, a la vez, crea un nuevo público [1961: 219-20]. El escritor colonizado y asimilacionista producía para el opresor - para halargarlo, pero también, eventualmente, para denunciarlo: progresivamente, el intelectual habrá de adoptar el hábito de «dirigirse a su pueblo». Ni que decir tiene que en el momento de la epifanía de la literatura nacional, el escritor se dirige ya plenamente a él -y no al opresor-y para ello debe también reformular y clarificar los temas típicamente nacionales.

En este esquema progresivo, el lugar de la literatura oral y la cultura popular no es del todo claro. En principio, parece que, a medida que se realiza el paso del asimilacionismo literario a la literatura nacional se produce también una transformación de cuentos, epopeyas y cantos populares, mediante la actualización de los conflictos y el renacimiento del sentimiento heroico y, por tanto, de la épica oral verdadera [1961: 220-221]: desaparecerían la comedia o la farsa y florecerían todas aquellas formas que revelan al público un «nuevo tipo de hombre». La renovación de intenciones comportaría además una reestructuración de la percepción. La liberación literaria es paralela, por tanto, a la liberación integral, política y psicológica del colonizado. El proceso de desalienación es, de este modo, un proceso también literario o, quizá, eminentemente literario, porque se lleva a cabo en el ámbito del espíritu y de la conciencia, y no en el de la lucha armada o el enfrentamiento político.

\section{BIBLIOGRAFIA CITADA}

Anthologie de la nouvelle poésie négre et malgache de langue française, [1948]: vid. Senghor, L. S.

ASAD, TALAL, ed., Anthropology and the Colonial Encounter, London, Ithaca Press, 1973.

AshCroft, Bill \& Griffiths, Gareth \& Tiffin, Helen, eds., The Empire Writes Back. Theory and Practice in Post-Colonial Literatures, London \& New York, Routledge, 1989.

BhaвнA, H. K.: «Foreword. Remembering Fanon: Self, Psyche and the Colonial Condition», en Franz Fanon, Black Skins, White Masks, trad. Ch. L. Markmann, London, Pluto Press, 1986 y en P. Williams \& L. Chrisman, eds., Colonial Discourse and Post-Colonial Theory. A Reader [1993, pp. 112-123]. 
- «Interrogating Identity: Franz Fanon and the Colonial Prerogative», en David Goldberg ed., The Anatomy of Racism [1990] y con correcciones en H. Bhabha, The Location of Culture, New York, Routledge, 1994, pp 40-65.

BUtLer, WILlie L.: «A Philo-Historical Analysis of Negritude», en Hommage a Léopold Sedar Senghor, Homme de Culture [1976: 342-350].

CÉSAIRE, AIME: Cahier d'un retour au pays natal [1939], en Césaire, La poésie [1994: 7-61].

- Discours sur le colonialisme [1951], Paris, Présence Africaine, 1955.

- Une tempête (d'après La Tempête de Shakespeare, adaptation pour un théâtre nègre) [1969], Paris, Seuil, 1975.

- La poésie, ed., Daniel Maximin \& Gilles Carpentier, Paris, Seuil, 1994.

- «Césaire reçoit Senghor», en Hommage à Léopold Sedar Senghor, Homme de Culture [1976: 41-48].

CheVRIER, JACQues: Littérature négre, Paris, Armand Colin, 1984.

- «Las literaturas africanas en el campo de la investigación comparatista», en Vega, M. J. \& Carbonell, N., La literatura comparada. Principios y métodos, Madrid, Gredos, 1998.

Childs, Peter \& Williams, R. J. Patrick: An Introduction to Post-Colonial Theory, London, Harvester Wheatsheaf, 1997.

CLIFFORD, JAMES: The Predicament of Culture: Twentieth-Century Ethnography, Literature, and Art, Cambridge Mass., Harvard University Press, 1988.

CORNEVIN, ROBERT, Littératures d' Afrique noire d'expression française, Paris, PUF, 1976.

Fanon, Franz: Peau Noire, Masques Blanches, Paris, Seuil, 1952.

- Les damnés de la terre, Paris, Maspero, 1961.

Franco, JEAN, «Beyond Ethnocentrism: Gender, Power and the Third-World Intelligentsia», en C. Nelson \& L. Grossberg, eds., Marxism and the Interpretation of Culture, London, Macmillan, 1988. Rpt. en Williams \& Chrisman [1993: 359-370].

Gabriel, Teshome H. «Towards a Critical Theory of Third-World Films», en Jim Pines \& Paul Willeman, eds., Questions of Third World Cinema, London, BFI, 1989, pp. 30-52.

GaTES, HENRY LoUIS: «Critical Fanonism», Critical Inquiry, 17 (1991) 457-470.

GeISMAR, PETER: Fanon, New York, Dial, 1970.

GoRDon, Lewis R.: Fanon and the Crisis of the European Man, New York, Routledge, 1995.

HAUSSER, MICHEL: Essai sur la poétique de la négritude, Lille, AR Thèses, 1982.

- Hommage a Léopold Sedar Senghor, Homme de Culture, Paris, Présence Africaine, 1976.

JAHN, J.: Las literaturas neoafricanas [1966], Madrid, Guadarrama, 1971.

JOUBERT, J.-L \& LECARME, J. \& TABONE, E. \& VERCIER, B.: Les littératures francophones depuis 1945, Paris, Bordas, 1986. 
KeSTELOOT, Les écrivains noirs de langue française: naissance d'une littérature, Bruxelles, Université Libre de Bruxelles, 1975.

LECLERC, GERARD: Anthropologie et colonialisme, Paris, Fayard, 1972.

LEIRIS, MICHEL: «L'ethnographe devant le colonialisme» en Les temps modernes, 58, 8 (1950), rp. en Brisées, Paris, Mercure de France, 1966, 125-145.

LEUSSE, HUBERT DE: Léopold Sedar Senghor l'africain, Paris, Hatier, 1967.

MANNONI, OCTAVE: La psychologie de la colonisation, Paris, Seuil, 1950. Trad. ing., Prospero and Caliban: The Psychology of Colonization, New York, Praeger, 1964.

MARIÁTEGUI, JosÉ CARLOS: Siete ensayos sobre la realidad peruana (192\%), versión digital de la Fundación José Carlos Mariátegui, 1996.

MOURA, J. M.: «Francophonie et critique postcoloniale», Revue de Litttérature Comparée, 281.1 (1997) 59-87.

PARRY, B.: «Problems in Current Theories of Colonial Discourse», Oxford Literary Review, 9.1-2 (1987) 75-58.

Posnock, Ross: «How It Feels To Be A Problem: Du Bois, Fanon, and the «Impossible Life» of the Black Intellectual», Critical Inquiry, 23.2 (1997) 323-349.

SAID, EDWARD: Orientalism, New York, Vintage, 1978.

- Culture and Imperialism, New York \& London: Vintage, 1993. Cito por la edición londinense de 1994.

SARTRE, JeAN-PaUl: Orphée noir, en Senghor, Léopold L., ed., Anthologie de la nouvelle poésie négre et malgache de langue française, [1948], Paris, PUF, 1969.

- Qu' est-ce que la littérature?, Paris, Gallimard, 1948.

- Réflexions sur la question juive, Paris, Gallimard, 1954.

- «Préface» en Fanon, Franz, Les damnés de la terre, Paris, Maspero, 1961, rpt. en Oeuvres, III: Prefaces critiques, Paris, Vrin, 1982.

Segal, Ronald: Perfiles africanos [1962], Buenos Aires, Eudeba, 1964.

SEnghor, LEopold S.: Chants d'ombre, Paris, Seuil, 1945. Y en Poèmes [1964 / 1973: 5-50].

- Ethiopiques [1956], en Poètes d'aujourd'hui. Léopold Sedar Senghor, [1961: 153-175] y en Poemes [1964 / 1973: 95-166].

- Poètes d'aujourd' hui. Léopold Sedar Senghor, ed. Armand Guibert, Paris, Pierre Seghers, 1961.

- Poemes [1964], Paris, Seuil, 1973.

- Liberté I. Négritude et humanisme, Paris, Seuil, 1964.

- Liberté II. Nation et voie africaine du socialisme, Paris, Seuil, 1971.

- «Réponse de Senghor a Césaire: La négritude comme culture des peuples noirs, ne saurait être dépassé» [vid. s.v. Césaire, "Césaire reçoit Senghor»], en Hommage a Léopold Sedar Senghor, Homme de Culture [1976: 49-60].

- Liberté III. Négritude et civilisation de l'universel, Paris, Seuil, 1977.

- The Africa Reader, London, Vintage, 1970. 
SENGHOR, LÉOPOLD S., ed. Anthologie de la nouvelle poésie négre et malgache de langue française, [1948] Paris, PUF, 1969.

Tenreiro, Francisco \& Pinto de Andrade, Mário, eds., Poesia negra de expressâo portuguesa, [1953] Lisboa \& Linda-a-Velha, Editor Africa, 1982.

VERGĖS, FrançOISE: «Creole Skin, Black Mask: Fanon and Disavowal», Critical Inquiry, 23.5 (1997) 578-596.

Williams, P. \& L. Chrisman, eds., Colonial Discourse and Post-Colonial Theory. A Reader, New York, Harvester Wheatsheaf, 1993.

Young, RoBert: Colonial Desire. Hybridity in Theory, Culture and Race, London \& New York, Routledge, 1995.

\section{FILMOGRAFIA}

Frantz Fanon: Black Skins, White Masks [1996/Reino Unido / documental / 70 min. $135 \mathrm{~mm}$. / color / francés e inglés con subtítulos franceses de I. Juhasz-Lacourt]. Guión de Isaac Julien y Mark Nash basado en los escritos de F. Fanon. Producción de Mark Nash, Normal Films. Dirección de Isaac Julien. 